\title{
Influence of non-thermal processing techniques on sulfur dioxide and oxygen concentrations in young and aged wines
}

\author{
Katarina Lukić ${ }^{1}$, Marina Tomašević1 ${ }^{1}$ Natka Ćurko ${ }^{1}$, Antonio Sivrić, Edi Ružman, Karin Kovačević Ganić ${ }^{1 *}$ \\ ${ }^{1}$ University of Zagreb, Faculty of Food Technology and Biotechnology, Pierottijeva 6, 10000 Zagreb, Croatia \\ *Corresponding author: kkova@pbf.hr
}

\begin{abstract}
The application of innovative techniques like high hydrostatic pressure (HHP) and high power ultrasound (HPU) for food processing and preservation is one of the current topics in food science. In the enological field, these techniques have been identified as alternative methods for wine microbial stabilization and acceleration of wine aging process. Due to lack of available information about their influence on physicochemical characteristics, the aim of this work was to study the effect of HHP and HPU on sulfur dioxide and dissolved oxygen concentrations in red and white wines. The effect was evaluated immediately after the treatment and after 3, 6 and 12 months of aging in bottles. Moreover, the synergistic effect of mentioned techniques along with antioxidants additions (glutathione and $\mathrm{SO}_{2}$ ) was also evaluated. The results showed that the concentrations of free and total $\mathrm{SO}_{2}$ did not change immediately after HHP treatments, while after HPU processing there was no clear trend in analyzed parameters. As expected, results showed that both, free and total $\mathrm{SO}_{2}$ decreased during storage period of red and white wines. Regarding both applied techniques, slightly higher concentrations of free $\mathrm{SO}_{2}$ were observed in samples treated by HHP after 12 months of storage. Oxygen concentration slightly increased immediately after the treatments, with the highest concentration determined after HPU processing. During aging, its concentrations decreased and were similar or slightly higher than of those determined in untreated samples. Regarding the antioxidants additions, better protective effect was obtained by addition of higher concentration of $\mathrm{SO}_{2}$ than glutathione, since these samples were characterized by lower concentrations of dissolved oxygen.
\end{abstract}

Keywords: high hydrostatic pressure, high power ultrasound, wine, sulfur dioxide, dissolved oxygen

\begin{abstract}
Sažetak
Primjena inovativnih tehnika kao što su visoki hidrostatski tlak (HHP) i ultrazvuk visokih snaga (HPU) u preradi i konzerviranju hrane jedna je od aktualnih tema u znanosti o hrani. U enološkom području, ove su tehnike prepoznate kao alternativne metode za mikrobiološku stabilizaciju vina i ubrzavanje procesa starenja vina. Uslijed nedostatka dostupnih informacija o utjecaju navedenih tehnika na fizikalno-kemijske karakteristike vina, cilj ovog rada bio je istražiti utjecaj HHP i HPU tretmana na koncentraciju sumporovog dioksida i otopljenog kisika u crnom i bijelom vinu. Utjecaj ovih tehnika utvrđen je neposredno nakon tretmana te nakon 3, 6 i 12 mjeseci starenja u bocama. Nadalje, ispitan je i sinergistički učinak navedenih tehnika i dodatka antioksidansa (glutation i $\mathrm{SO}_{2}$ ). Rezultati su pokazali da se koncentracija slobodnog i ukupnog $\mathrm{SO}_{2}$ nije promijenila odmah nakon HHP tretmana, dok nakon obrade HPU nema jasnog trenda u analiziranim parametrima. Kao što je bilo očekivano, koncentracija slobodnog i ukupnog $\mathrm{SO}_{2}$ se smanjila tijekom perioda starenja crnog i bijelog vina. Obzirom na primijenjene tehnike, najveće koncentracije slobodnog $\mathrm{SO}_{2}$ određene su u uzorcima tretiranim HHP-om, posebice nakon 12 mjeseci starenja. Odmah nakon tretmana, koncentracija kisika je lagano porasla, pri čemu je najveća koncentracija utvrđena nakon HPU tretmana. Tijekom starenja utvrđeno je smanjenje koncentracije kisika, čije su vrijednosti bile slične ili neznatno veće od onih utvrđenih u netretiranim uzorcima. Što se tiče dodatka antioksidansa, bolji zaštitni učinak postignut je dodatkom više koncentracije $\mathrm{SO}_{2}$ nego glutationa, obzirom da te uzorke karakteriziraju niže koncentracije otopljenog kisika.
\end{abstract}

Ključne riječi: visoki hidrostatski tlak, ultrazvuk visokih snaga, vino, sumporov dioksid, otopljeni kisik

\section{Introduction}

During last several years, physical techniques like high hydrostatic pressure (HHP) and high power ultrasound (HPU) have become of great interest in wine sector. Namely, the main advantage of their application is the reduction or even removal of chemical additives during wine production that may affect human health. The use of these techniques on wine should provide the antimicrobial effect and the preservation of aroma, taste and color properties at the same time.

Previous studies have already reported that HHP is able to inactivate undesirable microorganisms in red and white wines without affecting the sensory characteristics (Buzrul et al., 2012; Mok et al., 2006; Morata et al., 2012; Puig et al., 2008; van Wyk et al., 2018), suggesting that HHP might be a suitable alternative to reduce or replace $\mathrm{SO}_{2}$ addition in wine production. In addition, HHP has also been proposed as a rapid and easy method for initiating the chemical reactions in wine by providing the activation energy (Liu et al., 2018; Norton and Son, 2008). With regard to HPU, this technique has been highlighted as a promising method for wine processing, since cavitation phenomena generated by ultrasonic waves in liquid medium can induce certain chemical reactions and accelerate reaction rates (Chemat et al., 2011; García and Sun, 2013; Zhang et 
al., 2015). Herein, the use of HPU in wine technology has been often emphasized in terms of acceleration of wine aging process (Liu et al., 2015; Tao et al., 2014; Zhang and Wang, 2017), extraction improvement (Cabredo-Pinillos et al., 2006; Clodoveo et al., 2016; Plaza et al., 2019) and microbial stabilization (Cui et al., 2012; Luo et al., 2012; Jiranek et al., 2008).

Despite mentioned benefits of presented physical techniques, the replacement of antioxidant and antimicrobial effect of $\mathrm{SO}_{2}$ is a difficult task. However, the combination of physical technique and lower concentration of $\mathrm{SO}_{2}$ could help to reduce its use during the wine production. As a first step to determine the possibilities of using physical techniques in this field, it is necessary to evaluate their short- and long-term impact on sulfur dioxide and oxygen concentrations, as one of the main parameters employed for the assessment of wine quality. To date, there is still little information available regarding the influence of HHP and HPU on sulfur dioxide and dissolved oxygen in wines. Although their quantities depend on numerous factors, sulfur dioxide and oxygen concentrations in wine are still useful parameters in analyzing its condition.

During winemaking, the excessive contact of wine with oxygen may lead to oxidation (Fracassetti et al., 2013). Additionally, when wine is exposed to oxygen, the reactions between oxygen and wine antioxidants (phenolics, sulfur dioxide and glutathione) take place (Dimkou et al., 2013; Fracassetti et al., 2013). As a consequence, numerous modifications can occur in wine, such as decrease in dissolved oxygen and sulfur dioxide content. The moderate contact between wine and air is viewed as potentially favorable to improve color and flavor stability, particularly for red wines, but too much oxygen can lead to many problems, such as oxidative browning and loss of fresh and fruity aromas (Tomašević, 2017). Hence, the oxygen and $\mathrm{SO}_{2}$ control during wine production process must be considered since they have an important impact on the sensory characteristics of wine. The aim of this study was (i) to evaluate the short-term effects of HHP and HPU treatments on the sulfur dioxide and oxygen concentrations in young red and white wines, and (ii) to study the long-term effects of HHP and HPU along with antioxidants additions ( $\mathrm{SO}_{2}$ and glutathione) on sulfur dioxide and oxygen concentrations in red and white wines during 12 months of storage.

\section{Materials and methods}

\section{Wines}

The young wines comprised the varieties of Cabernet Sauvignon and Graševina, and were obtained from winery Erdutski vinogradi, Erdut, Croatia, during vintage 2016. The physicochemical composition of red wine Cabernet Sauvignon was: alcoholic strength, by volume $13.1 \%$, $\mathrm{pH} 3.46$, total acidity $5.3 \mathrm{~g} / \mathrm{L}$ as tartaric acid and volatile acidity 0.61 $\mathrm{g} / \mathrm{L}$ as acetic acid, free $\mathrm{SO}_{2} 10 \mathrm{mg} / \mathrm{L}$ and total $\mathrm{SO}_{2} 20 \mathrm{mg} / \mathrm{L}$, while those of white wine Graševina were: alcoholic strength, by volume $11.4 \%$, $\mathrm{pH} 3.37$, total acidity $5.1 \mathrm{~g} / \mathrm{L}$ as tartaric acid and volatile acidity 0.31 $\mathrm{g} / \mathrm{L}$ as acetic acid, free $\mathrm{SO}_{2} 25 \mathrm{mg} / \mathrm{L}$ and total $\mathrm{SO}_{2} 70 \mathrm{mg} / \mathrm{L}$.

High hydrostatic pressure (HHP) treatments

The $100 \mathrm{~mL}$ of wine was poured into plastic bottle, packed in individual plastic bag and placed in the pressure chamber with maximum capacity of $2 \mathrm{~L}$ with propylene glycol as the compression fluid. A high hydrostatic pressure system FPG7100 (Stansted Fluid Power, Harlow, UK) was used for HHP treatments. The combination of following process parameters: pressures (200, 400 and $600 \mathrm{MPa})$ and pressure holding times (5, 15 and $25 \mathrm{~min}$ ), was applied to assess the possible effects of the HHP treatment. All the treatments were carried out in triplicate and at room temperature $\left(25^{\circ} \mathrm{C}\right)$. Control sample represents the untreated wine sample. Samples were analyzed immediately after the HHP treatments.
High power ultrasound (HPU) treatments

For HPU treatments, an ultrasonic bath (Elmasonic P, Elma Schmidbauer $\mathrm{GmbH}$, Singen, Germany) and an ultrasonic probe (Q700, Qsonica Sonicators, Newton, CT, USA) were used for various process conditions as described below.

To study the effects of ultrasonic bath treatment, the wine samples were sonicated at different combinations of following process parameters: ultrasound frequencies (37 and $80 \mathrm{kHz})$, ultrasound amplitudes $(40,60$ and $100 \%)$, bath temperatures $\left(20,40\right.$ and $\left.60{ }^{\circ} \mathrm{C}\right)$ and treatment durations $(20,50,65$ and $90 \mathrm{~min})$ (Table 1). The wine samples $(200 \mathrm{~mL})$ were placed in a round-bottom glass vessel $(400 \mathrm{~mL})$, which served as a treatment chamber, and then immersed in the ultrasonic bath. The constant temperature of water inside the bath was kept by addition of cold water.

To study the effects of ultrasonic probe treatment, the combination of following process parameters, diameters of probes (12.7, 19.1 and 25.4 $\mathrm{mm})$, ultrasound amplitudes $(25,50,75$ and 100\%) and treatment durations (3, 6 and $9 \mathrm{~min}$ ), was applied (Table 1). Each HPU probe was centered and immersed $(2 \mathrm{~cm})$ in a glass reactor $(400 \mathrm{~mL})$ containing $300 \mathrm{~mL}$ of the sample. The system was set at nominal power of 700 $\mathrm{W}$ and a constant frequency of $20 \mathrm{kHz}$. The wine samples were kept at $25^{\circ} \mathrm{C}$ by cooling the reactor with cold water during the treatments.

All experimental trials of both HPU treatments were performed in triplicate. The control samples in both HPU treatments were untreated wines. Samples were analyzed immediately after the HPU treatments. 
Table 1. Experimental trials for ultrasonic bath and ultrasonic probe treatments

\begin{tabular}{|c|c|c|c|c|c|}
\hline \multicolumn{6}{|c|}{ Ultrasonic bath treatments } \\
\hline Run & $\mathrm{A}(\%)-\mathrm{f}(\mathrm{kHz})-\mathrm{T}\left({ }^{\circ} \mathrm{C}\right)-\mathrm{t}(\mathrm{min})$ & Run & $\underset{(\min )}{\mathrm{A}(\%)-\mathrm{f}(\mathrm{kHz})-\mathrm{T}\left({ }^{\circ} \mathrm{C}\right)-\mathrm{t}}$ & Run & $\mathrm{A}(\%)-\mathrm{f}(\mathrm{kHz})-\mathrm{T}\left({ }^{\circ} \mathrm{C}\right)-\mathrm{t}(\mathrm{min})$ \\
\hline 1 & $100-80-20-20$ & 25 & $60-80-20-20$ & 49 & $40-80-20-20$ \\
\hline 2 & $100-80-20-50$ & 26 & $60-80-20-50$ & 50 & $40-80-20-50$ \\
\hline 3 & $100-80-20-65$ & 27 & $60-80-20-65$ & 51 & $40-80-20-65$ \\
\hline 4 & $100-80-20-90$ & 28 & $60-80-20-90$ & 52 & $40-80-20-90$ \\
\hline 5 & $100-80-40-20$ & 29 & $60-80-40-20$ & 53 & $40-80-40-20$ \\
\hline 6 & $100-80-40-50$ & 30 & $60-80-40-50$ & 54 & $40-80-40-50$ \\
\hline 7 & $100-80-40-65$ & 31 & $60-80-40-65$ & 55 & $40-80-40-65$ \\
\hline 8 & $100-80-40-90$ & 32 & $60-80-40-90$ & 56 & $40-80-40-90$ \\
\hline 9 & $100-80-60-20$ & 33 & $60-80-60-20$ & 57 & $40-80-60-20$ \\
\hline 10 & $100-80-60-50$ & 34 & $60-80-60-50$ & 58 & $40-80-60-50$ \\
\hline 11 & $100-80-60-65$ & 35 & $60-80-60-65$ & 59 & $40-80-60-65$ \\
\hline 12 & $100-80-60-90$ & 36 & $60-80-60-90$ & 60 & $40-80-60-90$ \\
\hline 13 & $100-37-20-20$ & 37 & $60-37-20-20$ & 61 & $40-37-20-20$ \\
\hline 14 & $100-37-20-50$ & 38 & $60-37-20-50$ & 62 & $40-37-20-50$ \\
\hline 15 & $100-37-20-65$ & 39 & $60-37-20-65$ & 63 & $40-37-20-65$ \\
\hline 16 & $100-37-20-90$ & 40 & $60-37-20-90$ & 64 & $40-37-20-90$ \\
\hline 17 & $100-37-40-20$ & 41 & $60-37-40-20$ & 65 & $40-37-40-20$ \\
\hline 18 & $100-37-40-50$ & 42 & $60-37-40-50$ & 66 & $40-37-40-50$ \\
\hline 19 & $100-37-40-65$ & 43 & $60-37-40-65$ & 67 & $40-37-40-65$ \\
\hline 20 & $100-37-40-90$ & 44 & $60-37-40-90$ & 68 & $40-37-40-90$ \\
\hline 21 & $100-37-60-20$ & 45 & $60-37-60-20$ & 69 & $40-37-60-20$ \\
\hline 22 & $100-37-60-50$ & 46 & $60-37-60-50$ & 70 & $40-37-60-50$ \\
\hline 23 & $100-37-60-65$ & 47 & $60-37-60-65$ & 71 & $40-37-60-65$ \\
\hline 24 & $100-37-60-90$ & 48 & $60-37-60-90$ & 72 & $40-37-60-90$ \\
\hline \multicolumn{6}{|c|}{ Ultrasonic probe treatments } \\
\hline Run & $\mathrm{d}(\mathrm{mm})-\mathrm{A}(\%)-\mathrm{t}(\mathrm{min})$ & Run & $\mathrm{d}(\mathrm{mm})-\mathrm{A}(\%)-\mathrm{t}(\mathrm{min})$ & Run & $\mathrm{d}(\mathrm{mm})-\mathrm{A}(\%)-\mathrm{t}(\mathrm{min})$ \\
\hline 1 & $12.7-25-3$ & 13 & $19.1-25-3$ & 25 & $25.4-25-3$ \\
\hline 2 & $12.7-50-3$ & 14 & $19.1-50-3$ & 26 & $25.4-50-3$ \\
\hline 3 & $12.7-75-3$ & 15 & $19.1-75-3$ & 27 & $25.4-75-3$ \\
\hline 4 & $12.7-100-3$ & 16 & $19.1-100-3$ & 28 & $25.4-100-3$ \\
\hline 5 & $12.7-25-6$ & 17 & $19.1-25-6$ & 29 & $25.4-25-6$ \\
\hline 6 & $12.7-50-6$ & 18 & $19.1-50-6$ & 30 & $25.4-50-6$ \\
\hline 7 & $12.7-75-6$ & 19 & $19.1-75-6$ & 31 & $25.4-75-6$ \\
\hline 8 & $12.7-100-6$ & 20 & $19.1-100-6$ & 32 & $25.4-100-6$ \\
\hline 9 & $12.7-25-9$ & 21 & $19.1-25-9$ & 33 & $25.4-25-9$ \\
\hline 10 & $12.7-50-9$ & 22 & $19.1-50-9$ & 34 & $25.4-50-9$ \\
\hline 11 & $12.7-75-9$ & 23 & $19.1-75-9$ & 35 & $25.4-75-9$ \\
\hline 12 & $12.7-100-9$ & 24 & $19.1-100-9$ & 36 & $25.4-100-9$ \\
\hline
\end{tabular}

\footnotetext{
*A-Ultrasound amplitude, $f$-Ultrasound frequency, T-Bath temperature, $t$-Treatment duration, $d$-Diameter of the ultrasonic probe
}

** Control sample is untreated sample marked as experimental run 0 


\section{Wine treatments and bottle storage}

In order to study the long-term effects of HHP and HPU, the following process conditions for each technique and wine were applied: (i) pressure of $200 \mathrm{MPa}$ and treatment duration of $5 \mathrm{~min}$ for HHP treatment in the case of both red and white wines; (ii) ultrasound amplitude of $100 \%$, ultrasound frequency of $80 \mathrm{kHz}$, bath temperature of $27^{\circ} \mathrm{C}$ and treatment duration of $30 \mathrm{~min}$ for HPU treatment (ultrasonic bath) in the case of white wine, and (iii) probe diameter of $25.4 \mathrm{~mm}$, ultrasound amplitude of $25 \%$ and treatment duration of 6 min for HPU treatment (ultrasonic probe) in the case of red wine. Also, the experiment consisted of antioxidants additions ( $\mathrm{SO}_{2}$ and $\mathrm{GSH}$ ) in wines before processing to investigate the synergistic effect of their use along with mentioned techniques during 12 months of bottle aging (time $0,3,6$ and 12 months). Treated red and white wine samples were: (i) wine with standard $\mathrm{SO}_{2}$ concentration $\left(25 \mathrm{mg} / \mathrm{L}\right.$ of free $\mathrm{SO}_{2}$ for red wine; $45 \mathrm{mg} / \mathrm{L}$ of free $\mathrm{SO}_{2}$ for white wine), (ii) wine with low $\mathrm{SO}_{2}$ concentration and addition of $\mathrm{GSH}\left(10 \mathrm{mg} / \mathrm{L}\right.$ of free $\mathrm{SO}_{2}$ with $20 \mathrm{mg} / \mathrm{L}$ of GSH for red wine; $25 \mathrm{mg} / \mathrm{L}$ of free $\mathrm{SO}_{2}$ with $20 \mathrm{mg} / \mathrm{L}$ of GSH for white wine), and (iii) wine with low $\mathrm{SO}_{2}$ concentration $\left(10 \mathrm{mg} / \mathrm{L}\right.$ of free $\mathrm{SO}_{2}$ for red wine; $25 \mathrm{mg} / \mathrm{L}$ of free $\mathrm{SO}_{2}$ for white wine). Control wines were untreated wines with standard concentration of $\mathrm{SO}_{2}$. After HHP and HPU processing, the treated and untreated wines were bottled and sealed with natural corks in $750 \mathrm{~mL}$ glass wine bottles and stored under controlled conditions at $12{ }^{\circ} \mathrm{C}$ for 12 months. All treatments were performed in triplicate and analyses of sulfur dioxide and oxygen concentrations in wine were conducted after $0,3,6$ and 12 months of aging.

\section{Analyses of sulfur dioxide and oxygen concentrations in wine}

The dissolved oxygen measurements were performed using a luminescence-based technology (NomaSense ${ }^{\mathrm{TM}} \mathrm{O}_{2}$ P6000, Nomacorc, Belgium). This trace oxygen meter generates a blue light which is sent to the oxygen sensor via the optical fiber. The system corrects the concentration of oxygen in terms of sugar and alcohol content and wine temperature. To measure the oxygen concentration in wines, an immersion probe with a detection limit of $15 \mu \mathrm{g} / \mathrm{L}$ of oxygen was used.

Total and free $\mathrm{SO}_{2}$ were analyzed using a sulfur dioxide measurement device (LDS Sulfilyser, Laboratoires Dujardin-Salleron, Noizay, France). The measurement of $\mathrm{SO}_{2}$ is based on potentiometric titration which includes adding iodine until the electrode measures a change in redox potential.

\section{Data analysis}

The experimental results were presented as the mean values \pm standard deviation of six analytical repetitions. The statistical data analysis was performed by analysis of variance (ANOVA) using the Statistica V.10 software (StatSoft Inc., Tulsa, USA). Tukey's HSD Test was used as comparison test when samples analyses showed significant differences after ANOVA $(p<0.05)$.

\section{Results and discussion}

To investigate the possibility of using HHP and HPU techniques for managing the wine quality, the various experiments were performed on red and white wines. The results of the effects of different HHP treatments on the sulfur dioxide and oxygen concentrations in red and white wines are presented in Table 2 . As it can be observed, only slight changes occurred in the concentration of dissolved oxygen in both HHP treated red and white wines compared to control samples, while there were no significant changes $(p<0.05)$ in the concentrations of total and free $\mathrm{SO}_{2}$ in all experiments performed. Our results are in accordance with previous studies that showed that HHP treated and untreated wines maintained similar concentrations of free and total $\mathrm{SO}_{2}$, indicating that HHP did not affect the main wine quality parameters (Santos et al., 2016; Tabilo-Munizaga et al., 2014). Furthermore, the concentration of dissolved oxygen slightly increased in both wines after HHP, but there was no clear trend among applied treatments. This effect seems to be a combination of HHP treatments with a high permeability to oxygen of the polyethylene bottles that need to be used during HHP processing (Dombre et al., 2015; Santos et al., 2019). In addition, very little is known about the effect of HHP on the oxygen concentration in wine. Delfini et al. (1995) studied this effect and found that there was a decrease in dissolved oxygen concentration in HHP treated samples of Moscato wine, but only in the first 5 minutes after contact with air, whereas the oxygen concentration determined 6 hours after treatment was higher in the untreated samples than in the treated ones, but the same trend was not confirmed after 24 hours of the treatment.

Table 2. Effect of High Hydrostatic Pressure (HHP) treatments on the concentrations of dissolved oxygen, total and free $\mathrm{SO}_{2}$ in red and white wines

\begin{tabular}{|c|c|c|c|}
\hline \multicolumn{4}{|c|}{ Red wine } \\
\hline Treatments & Dissolved oxygen $(\mathrm{mg} / \mathrm{L})$ & Total $\mathrm{SO}_{2}(\mathrm{mg} / \mathrm{L})$ & Free $\mathrm{SO}_{2}(\mathrm{mg} / \mathrm{L})$ \\
\hline Control (untreated) & $1.21 \pm 0.00^{\mathrm{d}}$ & $20 \pm 0^{\mathrm{a}}$ & $10 \pm 1^{\mathrm{a}}$ \\
\hline $200 \mathrm{MPa} / 5 \mathrm{~min}$ & $1.90 \pm 0.16^{\mathrm{c}}$ & $20 \pm 0^{\mathrm{a}}$ & $10 \pm 1^{\mathrm{a}}$ \\
\hline $200 \mathrm{MPa} / 15 \mathrm{~min}$ & $1.99 \pm 0.08^{\mathrm{bc}}$ & $20 \pm 1^{\mathrm{a}}$ & $10 \pm 0^{\mathrm{a}}$ \\
\hline $200 \mathrm{MPa} / 25 \mathrm{~min}$ & $2.04 \pm 0.06^{\mathrm{bc}}$ & $19 \pm 1^{\mathrm{a}}$ & $10 \pm 1^{\mathrm{a}}$ \\
\hline $400 \mathrm{MPa} / 5 \mathrm{~min}$ & $1.89 \pm 0.13^{\mathrm{c}}$ & $20 \pm 0^{\mathrm{a}}$ & $10 \pm 1^{\mathrm{a}}$ \\
\hline $400 \mathrm{MPa} / 15 \mathrm{~min}$ & $2.13 \pm 0.19^{\mathrm{abc}}$ & $20 \pm 0^{\mathrm{a}}$ & $11 \pm 1^{\mathrm{a}}$ \\
\hline $400 \mathrm{MPa} / 25 \mathrm{~min}$ & $1.96 \pm 0.16^{\mathrm{bc}}$ & $20 \pm 1^{\mathrm{a}}$ & $11 \pm 1^{\mathrm{a}}$ \\
\hline $600 \mathrm{MPa} / 5 \mathrm{~min}$ & $2.47 \pm 0.36^{\mathrm{ab}}$ & $19 \pm 0^{\mathrm{a}}$ & $10 \pm 1^{\mathrm{a}}$ \\
\hline $600 \mathrm{MPa} / 15 \mathrm{~min}$ & $2.62 \pm 0.21^{\mathrm{a}}$ & $19 \pm 1^{\mathrm{a}}$ & $10 \pm 0^{\mathrm{a}}$ \\
\hline $600 \mathrm{MPa} / 25 \mathrm{~min}$ & $2.14 \pm 0.18^{\mathrm{abc}}$ & $19 \pm 1^{\mathrm{a}}$ & $10 \pm 1^{\mathrm{a}}$ \\
\hline \multicolumn{4}{|c|}{ White wine } \\
\hline Treatments & Dissolved oxygen $(\mathrm{mg} / \mathrm{L})$ & Total $\mathrm{SO}_{2}(\mathrm{mg} / \mathrm{L})$ & Free $\mathrm{SO}_{2}(\mathrm{mg} / \mathrm{L})$ \\
\hline Control (untreated) & $1.98 \pm 0.01^{\mathrm{d}}$ & $70 \pm 0^{\mathrm{a}}$ & $25 \pm 1^{\mathrm{a}}$ \\
\hline
\end{tabular}




\begin{tabular}{|c|c|c|c|}
\hline $200 \mathrm{MPa} / 5 \min$ & $2.07 \pm 0.03^{\mathrm{cd}}$ & $70 \pm 0^{\mathrm{a}}$ & $25 \pm 1^{\mathrm{a}}$ \\
\hline $200 \mathrm{MPa} / 15 \min$ & $2.14 \pm 0.10^{\mathrm{bcd}}$ & $70 \pm 0^{\mathrm{a}}$ & $24 \pm 1^{\mathrm{a}}$ \\
\hline $200 \mathrm{MPa} / 25 \min$ & $2.20 \pm 0.01^{\mathrm{bcd}}$ & $70 \pm 0^{\mathrm{a}}$ & $25 \pm 1^{\mathrm{a}}$ \\
\hline $400 \mathrm{MPa} / 5 \min$ & $2.29 \pm 0.15^{\mathrm{abc}}$ & $70 \pm 0^{\mathrm{a}}$ & $24 \pm 1^{\mathrm{a}}$ \\
\hline $400 \mathrm{MPa} / 15 \min$ & $2.41 \pm 0.03^{\mathrm{ab}}$ & $70 \pm 0^{\mathrm{a}}$ & $24 \pm 1^{\mathrm{a}}$ \\
\hline $400 \mathrm{MPa} / 25 \min$ & $2.37 \pm 0.03^{\mathrm{ab}}$ & $70 \pm 0^{\mathrm{a}}$ & $25 \pm 1^{\mathrm{a}}$ \\
\hline $600 \mathrm{MPa} / 5 \min$ & $2.25 \pm 0.06^{\mathrm{abcd}}$ & $70 \pm 0^{\mathrm{a}}$ & $25 \pm 1^{\mathrm{a}}$ \\
\hline $600 \mathrm{MPa} / 15 \min$ & $2.29 \pm 0.02^{\mathrm{abc}}$ & $70 \pm 0^{\mathrm{a}}$ & $24 \pm 1^{\mathrm{a}}$ \\
\hline $600 \mathrm{MPa} / 25 \min$ & $2.52 \pm 0.22^{\mathrm{a}}$ & \\
\hline
\end{tabular}

Regarding HPU, the effects of this technique on the sulfur dioxide and oxygen concentrations in red and white wines are shown in Figure 1. In general, the results showed that ultrasonic probe (Figure 1a and 1c) and ultrasonic bath (Figure 1b and 1d) treatments slightly influenced the concentrations of sulfur dioxide and dissolved oxygen in both, red and white wines. Compared to control samples, the concentration of dissolved oxygen slightly increased immediately after HPU treatments, while there was no clear trend in results for free and total $\mathrm{SO}_{2}$. This result is probably a consequence of dissolution of a certain amount of oxygen in wine during the measurement. In general, the quantity of dissolved oxygen in wine depends on various factors, such as temperature, $\mathrm{pH}$, atmospheric pressure and air exposure. Any operation involving contact with air, such as transferring, pumping or mixing, significantly accelerates the dissolution of oxygen (Ribéreau-Gayon et al., 2000). Regarding the effect of HPU on oxygen in wine, Singleton and Draper (1963) investigated the degree of oxidation after ultrasound in different atmospheres (air, nitrogen, and oxygen) and concluded that the use of ultrasound in the presence of air and nitrogen did not result in an increased oxidation while the oxygen atmosphere accelerated this process. Among different applied HPU techniques, slightly higher oscillations in concentration of sulfur dioxide and dissolved oxygen in both wines were observed after ultrasonic bath treatments. Our results are in agreement with the study of García et al. (2016) who also reported inconsistent data for the changes of sulfur dioxide in wine after ultrasound treatments. These authors suggested that degasification effect of ultrasound could be responsible for changes in the concentration of sulfur dioxide, particularly for the decrease of free $\mathrm{SO}_{2}$ in wine. On the other hand, Cui et al. (2012) found that ultrasound treatment did not affect the concentrations of free and total $\mathrm{SO}_{2}$ in white wine.

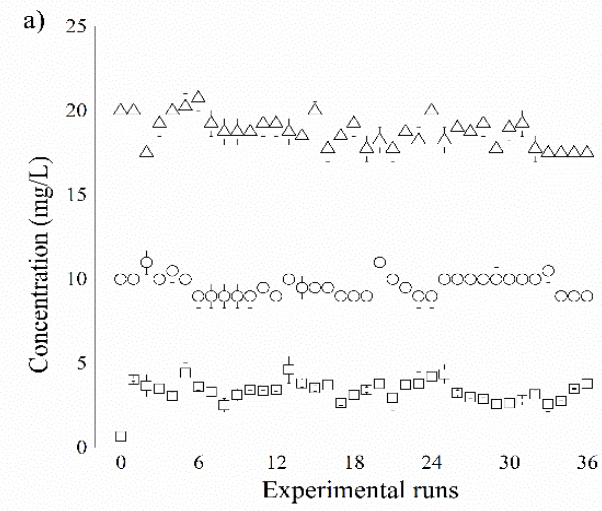

b) 25
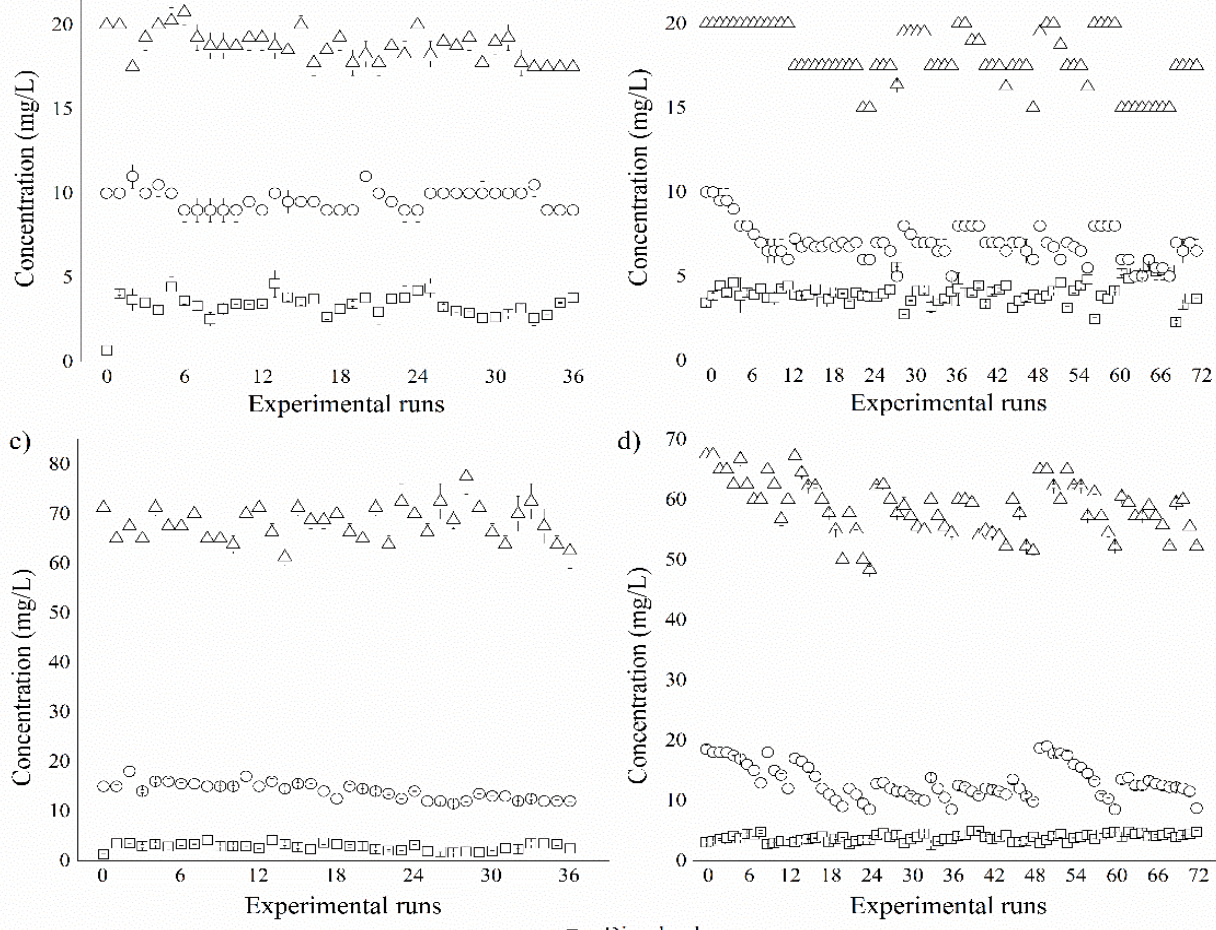

d)

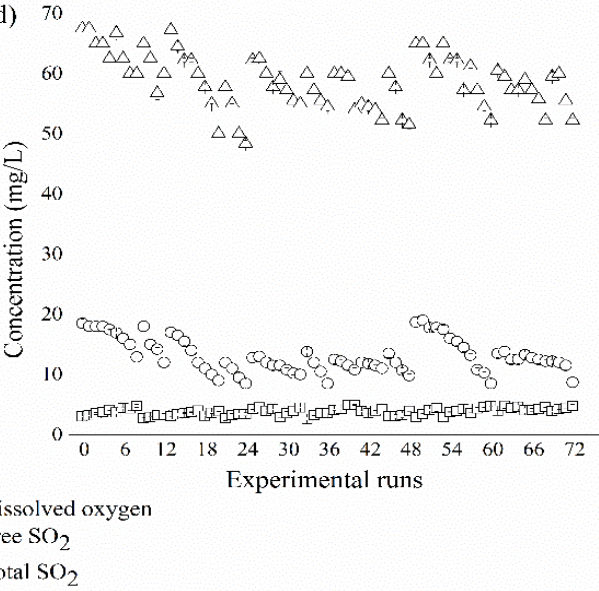

Figure 1. Effect of High Power Ultrasound (HPU) on the concentrations of dissolved oxygen, total and free $\mathrm{SO}_{2}$ in red and white wines. Red wine: a) ultrasonic probe, b) ultrasonic bath. White wine: c) ultrasonic probe, d) ultrasonic bath. 
Except of short-term effects of HHP and HPU treatments, the longterm effects of these techniques and antioxidants additions $\left(\mathrm{SO}_{2}\right.$ and $\mathrm{GSH}$ ) on the sulfur dioxide and oxygen concentrations in red and white wines during 12 months of bottle aging are summarized in Figure 2 and Figure 3, respectively. At the beginning of storage, no major difference among untreated and HHP treated red and white wine samples with standard concentration of $\mathrm{SO}_{2}$ was observed for all analyzed parameters, indicating that HHP did not affect the sulfur dioxide and dissolved oxygen concentrations in wines immediately after the treatment (Figure 2). Generally, independently of treatments applied, the oxygen can dissolve into the wine during bottling and later during aging process. Several authors have indicated the bottling process as a critical step for oxygen pickup (Dimkou et al., 2011; Skouroumounis et al., 2005; Vidal and Moutounet, 2006). For example, the filling of wine into the bottles can increase the concentration of dissolved oxygen by 0.5 to $2.0 \mathrm{mg} / \mathrm{L}$ (Peynaud, 1984). Furthermore, the oxygen that was trapped in the bottle headspace during the filling can also influence the final amount of dissolved oxygen in wine (Lopes et al., 2007). Also, one of the influencing factor during aging on wine composition, particularly sensory characteristics, is oxygen ingress through used closures (Caillé et al., 2010; Kwiatkowski et al., 2007; Wirth et al., 2012). In this study, the initial average concentrations of dissolved oxygen in wines prior to bottling were around 1.2-2.2 mg/L, while at the end of storage the concentrations were around $0.4 \mathrm{mg} / \mathrm{L}$ (Figure 2). The ranges of dissolved oxygen determined in this study are similar to that reported by other authors (Danilewicz, 2016; Dimkou et a., 2013; Fracassetti et al., 2013; Gambuti et al., 2017, Ling et al., 2019; Lopes et al., 2009; Waterhouse et al., 2016). Namely, dissolved oxygen in all wine samples started to decrease immediately after bottling and was consumed in the majority of the treatments in the first three months of aging. The concentration of free $\mathrm{SO}_{2}$ in control and HHP treated wines also decreased during bottle aging, with a faster decrease in the first 3 months followed by a slower decrease after 6 and 12 months of aging. In comparison with the beginning of storage, control (unpressurized) red wine showed 81, 43 and $42 \%$ less of dissolved oxygen, free and total $\mathrm{SO}_{2}$ after 12 months, respectively (Figure 2a-c). A similar trend can be also observed in HHP treated red wine samples during storage. In addition, slightly higher decrease of total $\mathrm{SO}_{2}(52 \%)$ was found in HHP treated red wine with standard concentration of $\mathrm{SO}_{2}$ during storage, while slightly lower decrease of $25 \%$ was noticed in wine samples with lower concentration of $\mathrm{SO}_{2}$. Moreover, it can be seen that the concentration of dissolved oxygen was influenced by the concentration and type of antioxidants used. Additionally, both antioxidants used, $\mathrm{SO}_{2}$ and $\mathrm{GSH}$, can react with quinones, altering the oxygen uptake toward the products, resulting in an increased oxygen uptake (Danilewicz et al., 2008; Danilewicz and Wallbridge, 2010), explaining the lower concentration of oxygen in wines with a higher concentration of $\mathrm{SO}_{2}$. Furthermore, it was already reported that HHP processing could lead to the generation of radicals and consequently alter the equilibrium of $\mathrm{SO}_{2}$ reaction in wine during aging (Santos et al., 2016; Tao et al., 2012). As expected, regarding the changes in concentration of sulfur dioxide and dissolved oxygen in white wine samples (Figure 2d-f), a decrease of dissolved oxygen, free and total $\mathrm{SO}_{2}$ was also detected in unpressurized and pressurized wines. After 12 months of aging, unpressurized white wine presented 74, 44 and $20 \%$ less of dissolved oxygen, free and total $\mathrm{SO}_{2}$, respectively, when compared with the beginning of storage. Furthermore, the HHP treated white wines also showed a similar trend during storage, where slightly higher decrease of free $\mathrm{SO}_{2}(52 \%)$ was determined in wine with standard concentration of $\mathrm{SO}_{2}$. As earlier stated, a higher decrease of $\mathrm{SO}_{2}$ concentration in HHP treated white wines during storage might be due to the possibility that free $\mathrm{SO}_{2}$ reacts with high reactive oxygen species formed from phenolic compounds during HHP treatment (Santos et al., 2016). On the other hand, HHP treated white wine samples with lower concentration of $\mathrm{SO}_{2}$ showed around 38 and $14 \%$ less of free and total $\mathrm{SO}_{2}$ comparing with the beginning of storage. In relation to the oxygen decrease in wine samples during storage, the possible explana- tion could be unavailability of both antioxidants used. It is known that in this state accelerated uptake of oxygen occurs due to production of radicals by Fenton's reaction, which then react fast with oxygen (Gambuti et al., 2015). Moreover, the loss of dissolved oxygen and total $\mathrm{SO}_{2}$ seems to be slightly faster in red wine than in white, independent from applied treatments. This is probably due to the fact that the rate of reaction of oxygen as well as $\mathrm{SO}_{2}$ mainly depends on the concentration of phenolic compounds available for oxidation (Morozova, 2014; Danilewicz and Wallbridge, 2010). For very long time it was considered that $\mathrm{SO}_{2}$ reacts direct with oxygen. However, this reaction is inhibited under the chemical conditions of wine. Specifically, the oxidation of $\mathrm{SO}_{2}$ in wine is prevented by the presence of phenolic compounds (Danilewicz, 2007). Namely, sulfites in wine react with hydrogen peroxide, which is an oxidation product of phenolic compounds (Boulton et al., 2013; Danilewicz and Wallbridge, 2010; Waterhouse and Laurie, 2006)

The effects of HPU treatments (ultrasonic probe and ultrasonic bath) and antioxidants additions ( $\mathrm{SO}_{2}$ and $\left.\mathrm{GSH}\right)$ on the concentration of sulfur dioxide and dissolved oxygen in red and white wines during 12 months of aging are presented in Figure 3. The results showed that at the beginning of storage, there were no great changes in analyzed parameters after applying HPU treatments comparing untreated and treated wine samples with standard concentration of $\mathrm{SO}_{2}$. As it was already mentioned, the role of oxygen during aging of bottled wine is very important and it depends on numerous factors. During bottle aging, wine is exposed to relatively small amounts of oxygen, but even these concentrations are sufficient to impact the outcome of aging process (Ugliano, 2013). In this study, the average concentrations of dissolved oxygen in wines prior to bottling were around 3.3-4.0 $\mathrm{mg} / \mathrm{L}$, while at the end of storage the concentrations were in range from 0.2 to $0.5 \mathrm{mg} / \mathrm{L}$, which is similar to those found in other studies (Danilewicz, 2016; Dimkou et a., 2013; Fracassetti et al., 2013; Gambuti et al., 2017, Ling et al., 2019; Lopes et al., 2009; Waterhouse et al., 2016). Immediately after bottling, a rapid decrease of dissolved oxygen can be observed in all treatments in the first three months of aging (Figure 3). Additionally, the concentration of free $\mathrm{SO}_{2}$ also decreased to a large extent in the same period of aging, while after 6 and 12 months of aging a slower decrease was perceived. Namely, the direct reaction between oxygen and $\mathrm{SO}_{2}$ is supremely slow in wine as medium (Waterhouse and Laurie, 2006), thus a decrease of $\mathrm{SO}_{2}$ is related to oxygen through reaction of $\mathrm{SO}_{2}$ with the products of wine oxidation, primarily hydrogen peroxide (Danilewicz et al., 2008). From the results of the ultrasonic probe treatment of red wine samples (Figure 3a-c), it can be seen that control (unsonicated) red wine presented 88, 61 and $24 \%$ less of dissolved oxygen, free and total $\mathrm{SO}_{2}$, respectively, when compared with the beginning of storage. A slightly higher decrease of dissolved oxygen and free $\mathrm{SO}_{2}$ (91 and 63\%) was found in HPU treated red wine sample with standard concentration of $\mathrm{SO}_{2}$, whereas slightly lower decrease of dissolved oxygen and free $\mathrm{SO}_{2}$, approximately 85 and $38 \%$, was noticed in HPU treated red wine samples with lower concentration of $\mathrm{SO}_{2}$ after 12 months of aging. Furthermore, the results of the ultrasonic bath treatment of white wine samples (Figure 3d-f) showed that, when compared with the beginning of storage, control white wine presented 95,44 and $20 \%$ less of dissolved oxygen, free and total $\mathrm{SO}_{2}$, respectively. HPU treated white wine sample with standard concentration of $\mathrm{SO}_{2}$ showed slightly higher decrease of free and total $\mathrm{SO}_{2}$ (66 and 25\%), while HPU treated white wine samples with lower concentration of $\mathrm{SO}_{2}$ presented slightly lower decrease of dissolved oxygen and total $\mathrm{SO}_{2}$, approximately 91 and $15 \%$ after 12 months of aging. The observed behaviors could be attributed to the degassing effect of ultrasound for which is known that accelerates removal of dissolved oxygen in liquids. Namely, dissolved oxygen can act as nuclei to form bubbles, which could float to the surface and be removed from the treated medium (Feng et al., 2011). Moreover, the ultrasound has the ability to induce free radicals, which are considered as important triggering factors to initiate chemical reactions in liquids. Additionally, it was confirmed that ultrasound triggers the generation of 
1-hydroxyethyl free radical into wine, which is considered to be a main radical intermediate in natural oxidation of wine (Zhang et al., 2015). When comparing all variations of wine samples regardless of HPU treatment applied, it is clearly that the presence of higher concentration of $\mathrm{SO}_{2}$ had a great effect on oxygen uptake. This observation was expected, since previous studies showed the same tendencies (Danilewicz et al., 2007; Danilewicz et al., 2008; Fracassetti et al., 2013). Also, the addition of GSH did not lead to an enlargement of the $\mathrm{SO}_{2}$ consumption rate, indicating that unlike other antioxidants, GSH does not increase the production of hydrogen peroxide, which consumes $\mathrm{SO}_{2}$ (Panero et al., 2015). Comparing both HHP and HPU techniques, the highest concentrations of free $\mathrm{SO}_{2}$ as well as the lowest concentrations of dissolved oxygen were determined in samples treated by HHP, particularly after 12 months of storage. Finally, independent from applied techniques, better protective effect was obtained by addition of higher concentration of $\mathrm{SO}_{2}$ than glutathione, since these samples were characterized by lower concentrations of dissolved oxygen. a)

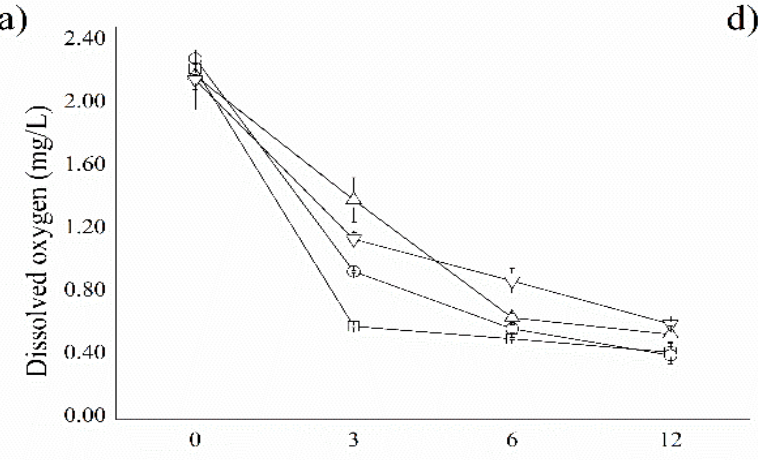

b)

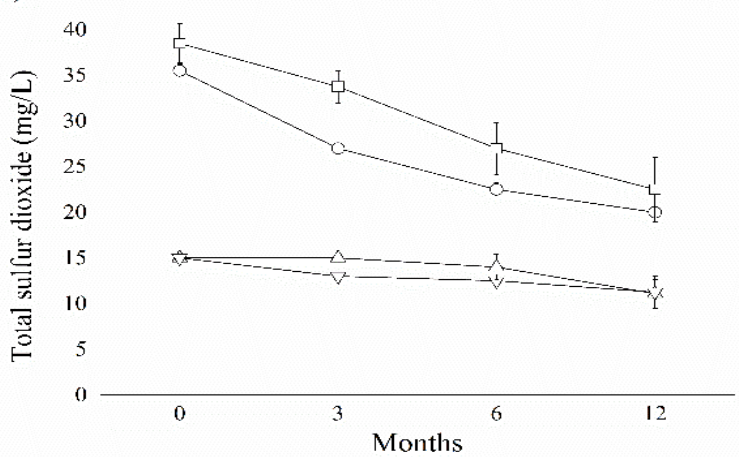

c) 30

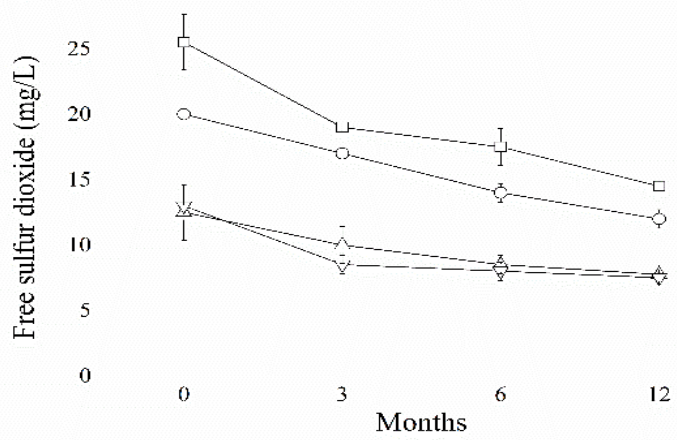

d)

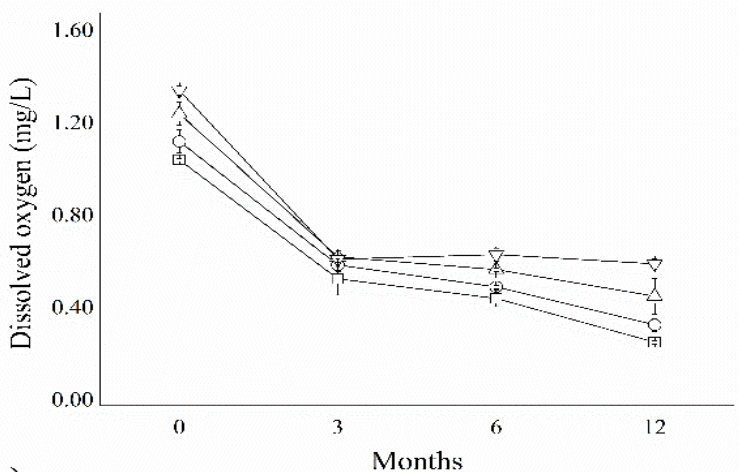

e)

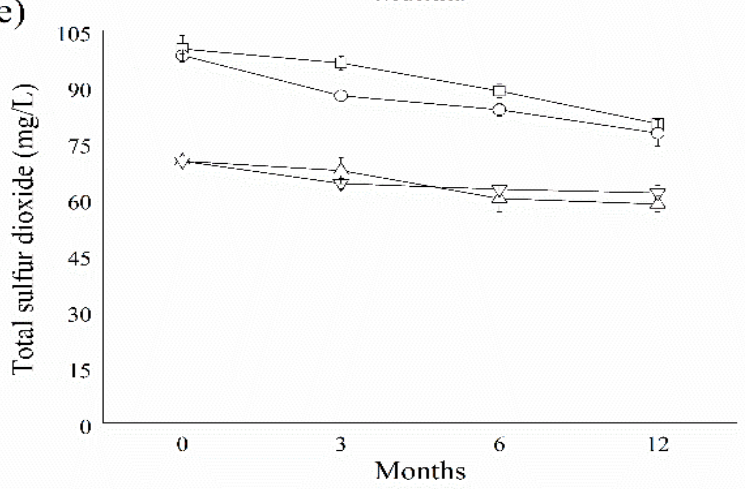

f)

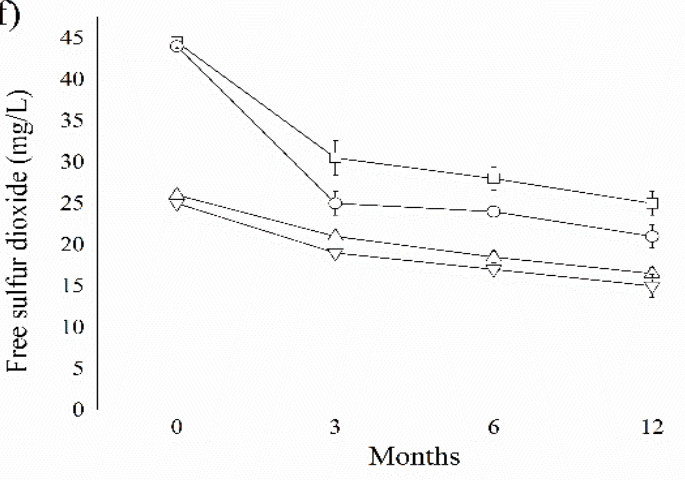

\footnotetext{
- - Control

- Standard $\mathrm{SO}_{2}$

$\triangle$ Low $\mathrm{SO}_{2}$ and GSII

$\rightarrow-$ Low $\mathrm{SO}_{2}$
}

Figure 2. Effects of High Hydrostatic Pressure (HHP) and antioxidants additions ( $\mathrm{SO}_{2}$ and GSH) on the concentrations of dissolved oxygen, total and free $\mathrm{SO}_{2}$ in red and white wines during 12 months of aging. HHP treatment of red wine samples $(a-c)$. HHP treatment of white wine samples $(d-f)$. 
a)

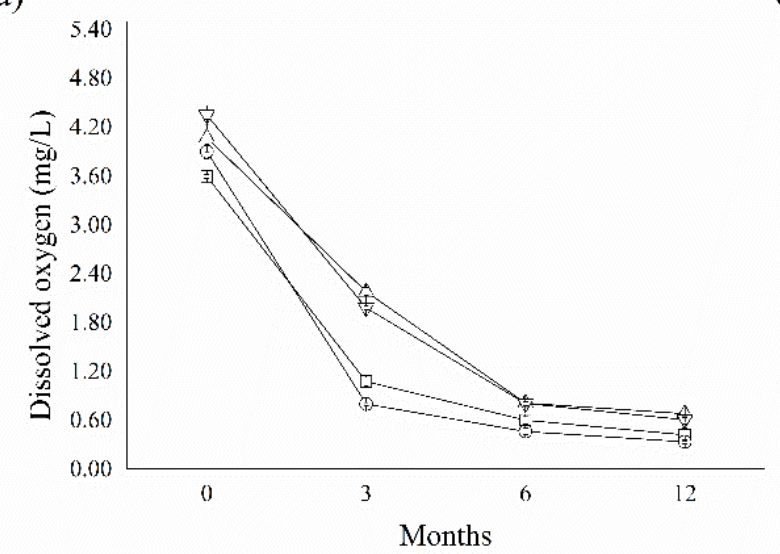

b)

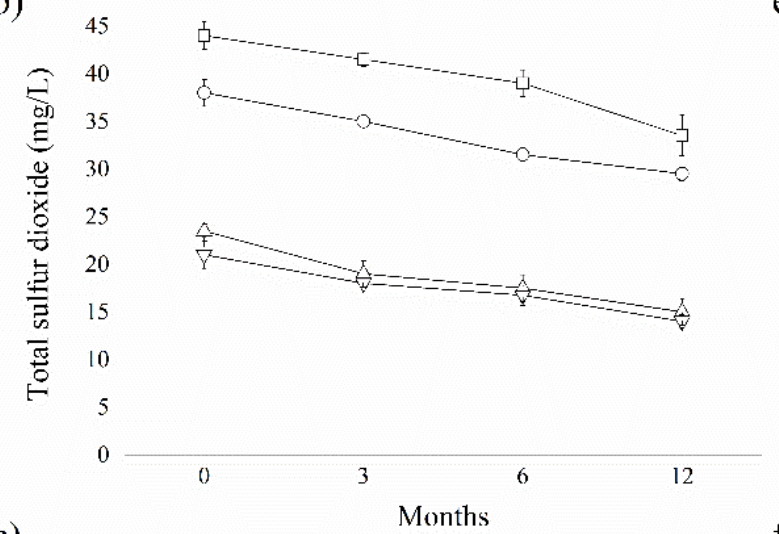

c)

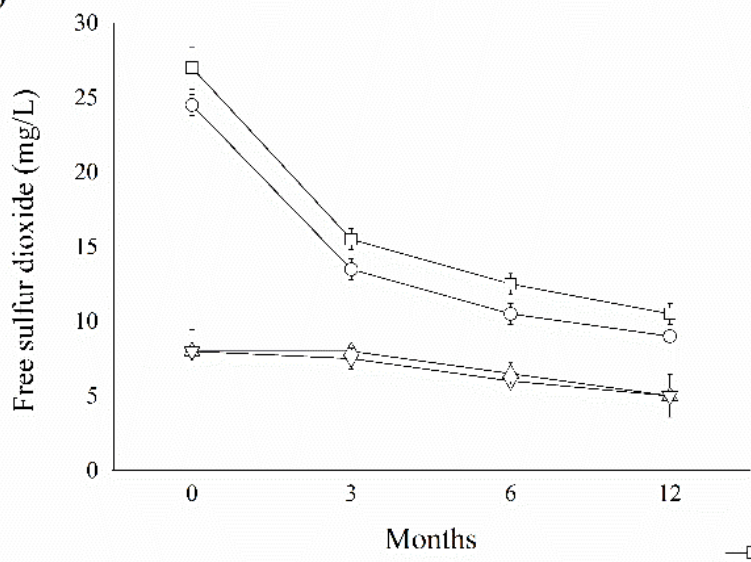

d)

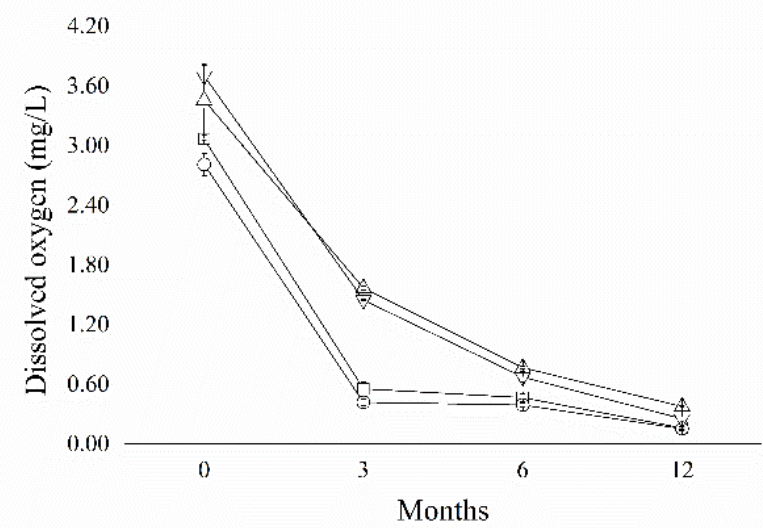

e)

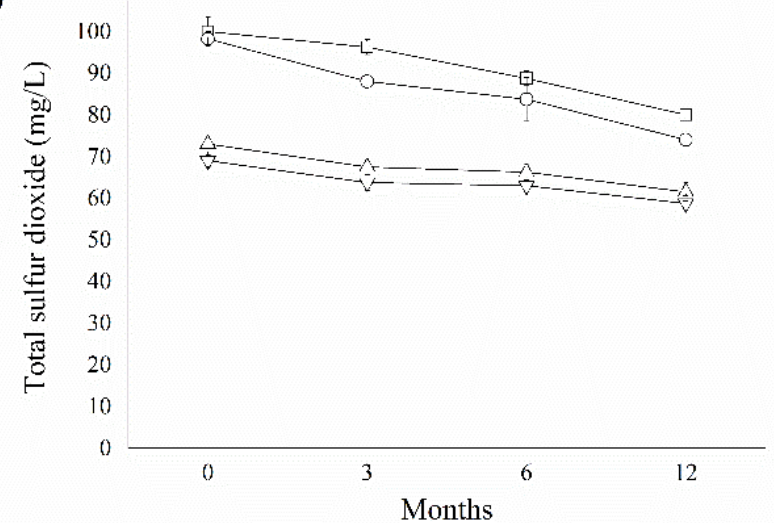

f)

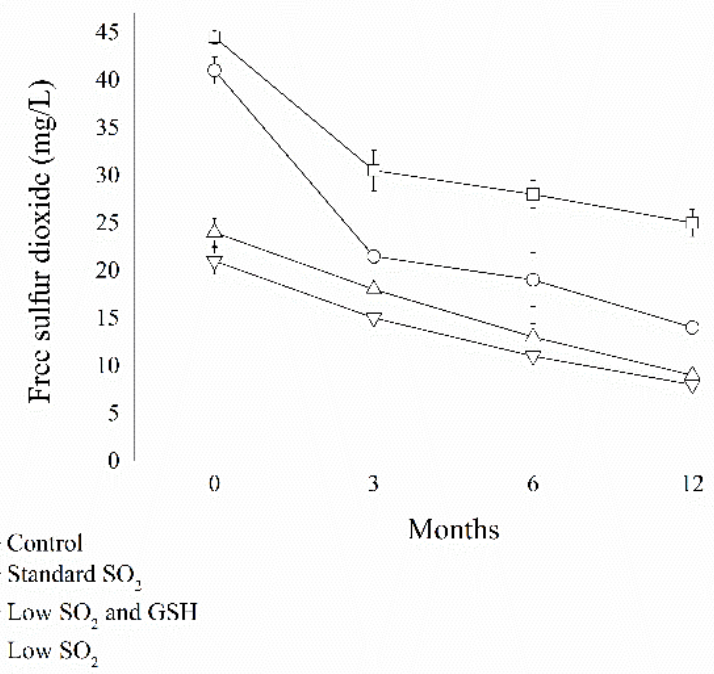

Figure 3. Effects of High Power Ultrasound (HPU) and antioxidants additions ( $\mathrm{SO}_{2}$ and GSH) on the concentrations of dissolved oxygen, total and free $\mathrm{SO}_{2}$ in red and white wines during 12 months of aging. Ultrasonic probe treatment of red wine samples $(a-c)$. Ultrasonic bath treatment of white wine samples $(d-f)$. 


\section{Conclusions}

In summary, this study showed that HHP did not affect both, free and total sulfur dioxide, immediately after the treatments, while there was no clear trend in its concentrations after application of HPU. Moreover, results showed that both, free and total $\mathrm{SO}_{2}$, decreased during storage period of red and white wines. After 12 months of storage, regarding both applied techniques, slightly higher concentrations of free $\mathrm{SO}_{2}$ were observed in samples treated by HHP. Dissolved oxygen concentration slightly increased immediately after the treatments, particularly after HPU processing. During aging, its concentrations decreased and were similar or slightly higher than of those determined in control, untreated samples. Among antioxidants used in all experiments performed, the addition of glutathione did not influence the oxygen and $\mathrm{SO}_{2}$ consump- tion rate in HHP and HPU treated red and white wines. Namely, better protective effect was obtained by addition of sulfur dioxide, since these samples were characterized by lower concentrations of dissolved oxygen. Altogether, our results demonstrated the importance of measuring the concentration of sulfur dioxide and dissolved oxygen in wine after exposure to HHP and HPU treatments. Finally, this research provided important insights for possible application of HHP and HPU techniques and lower concentrations of $\mathrm{SO}_{2}$ for production of high quality wines during storage. Nevertheless, it is important to investigate the effects of mentioned techniques on wine sensory and chemical characteristics (phenolic and aroma composition) in order to evaluate their efficiency in winemaking.

\section{Acknowledgments}

This paper has been funded by Croatian Science Foundation project IP-09-2014-3796.

\section{References}

Boulton, R. B., Singleton, V. L., Bisson, L. F., Kunkee, R. E. (2013) Principles and practices of winemaking. Springer Science \& Business Media, New York, USA.

Buzrul, S. (2012) High hydrostatic pressure treatment of beer and wine: A review. Innovative Food Science \& Emerging Technologies, 13 1-12.

Cabredo-Pinillos, S., Cedrón-Fernández, T., González-Briongos, M., Puente-Pascual, L., Sáenz-Barrio, C. (2006) Ultrasound-assisted extraction of volatile compounds from wine samples: Optimisation of the method. Talanta, 69(5) 1123-1129.

Caillé, S., Samson, A., Wirth, J., Diéval, J. B., Vidal, S., Cheynier, V. (2010) Sensory characteristics changes of red Grenache wines submitted to different oxygen exposures pre and post bottling. Analytica Chimica Acta, 660(1-2) 35-42.

Chemat, F., Khan, M. K. (2011). Applications of ultrasound in food technology: processing, preservation and extraction. Ultrasonics sonochemistry, 18(4) 813-835.

Clodoveo, M. L., Dipalmo, T., Rizzello, C. G., Corbo, F., Crupi, P. (2016) Emerging technology to develop novel red winemaking practices: An overview. Innovative Food Science \& Emerging Technologies, 38 41-56.

Cui, Y., Lv, W., Liu, J. F., Wang, B. J. (2012) Effect of different ending fermentation technologies on microbial-stability of Italian Riesling low alcohol sweet white wine. In: Chen, R., Sung, W.-P. (ed): Advanced Materials Research, str. 1165-1168. Trans Tech Publications, Zürich, Switzerland.

Danilewicz, J. C. (2007) Interaction of sulfur dioxide, polyphenols, and oxygen in a wine-model system: Central role of iron and copper. American Journal of Enology and Viticulture, 58(1) 53-60.

Danilewicz, J. C. (2016) Reaction of oxygen and sulfite in wine. American Journal of Enology and Viticulture, 67(1) 13-17.

Danilewicz, J. C., Seccombe, J. T., Whelan, J. (2008) Mechanism of interaction of polyphenols, oxygen, and sulfur dioxide in model wine and wine. American journal of enology and viticulture, 59(2) 128-136.

Danilewicz, J. C., Wallbridge, P. J. (2010) Further studies on the mechanism of interaction of polyphenols, oxygen, and sulfite in wine. American Journal of Enology and Viticulture, 61(2) 166-175.

Delfini, C., Conterno, L., Carpi, G., Rovere, P., Tabusso, A., Cocito, C., Amati, A. (1995) Microbiological stabilisation of grape musts and wines by high hydrostatic pressures. Journal of Wine Research, 6(2) 143-151.

Dimkou, E., Ugliano, M., Dieval, J. B., Vidal, S., Aagaard, O., Rauhut, D., Jung, R. (2011) Impact of headspace oxygen and closure on sulfur dioxide, color, and hydrogen sulfide levels in a Riesling wine. American Journal of Enology and Viticulture, 62(3) 261-269.

Dimkou, E., Ugliano, M., Diéval, J. B., Vidal, S., Jung, R. (2013) Impact of dissolved oxygen at bottling on sulfur dioxide and sensory properties of a Riesling wine. American Journal of Enology and Viticulture, 64(3) 325-332.

Dombre, C., Rigou, P., Wirth, J., Chalier, P. (2015) Aromatic evolution of wine packed in virgin and recycled PET bottles. Food chemistry, 176 


\section{6-387.}

Feng, H., Barbosa-Cánovas, G. V., Weiss, J. (2011) Ultrasound technologies for food and bioprocessing. Springer, New York, USA.

Fracassetti, D., Coetzee, C., Vanzo, A., Ballabio, D., Du Toit, W. J. (2013) Oxygen consumption in South African Sauvignon Blanc wines: Role of glutathione, sulphur dioxide and certain phenolics. South African Journal of Enology and Viticulture, 34(2) 156-169.

Gambuti, A., Han, G., Peterson, A. L., Waterhouse, A. L. (2015) Sulfur dioxide and glutathione alter the outcome of microoxygenation. American Journal of Enology and Viticulture, 66(4) 411-423.

Gambuti, A., Siani, T., Picariello, L., Rinaldi, A., Lisanti, M. T., Ugliano, M., Dieval, J. B., Moio, L. (2017) Oxygen exposure of tannins-rich red wines during bottle aging. Influence on phenolics and color, astringency markers and sensory attributes. European Food Research and Technology, 243(4) 669-680.

Jiranek, V., Grbin, P., Yap, A., Barnes, M., Bates, D. (2008) High power ultrasonics as a novel tool offering new opportunities for managing wine microbiology. Biotechnology letters, 30(1) 1-6.

Kwiatkowski, M. J., Skouroumounis, G. K., Lattey, K. A., Waters, E. J. (2007) The impact of closures, including screw cap with three different headspace volumes, on the composition, colour and sensory properties of a Cabernet Sauvignon wine during two years' storage. Australian Journal of Grape and Wine Research, 13(2) 81-94.

Ling, M. Q., Xie, H., Hua, Y. B., Cai, J., Li, S. Y., Lan, Y. B., Duan, C. Q., Shi, Y. (2019) Flavor Profile Evolution of Bottle Aged Rosé and White Wines Sealed with Different Closures. Molecules, 24(5) 836.

Liu, Y. W., Li, Q., Sun, H. B., Shang, D. J., Sun, J. D. (2015) The investigation on accelerating the aging of wine by ultrasonic wave. In: 2015 Symposium on Piezoelectricity, Acoustic Waves, and Device Applications (SPAWDA), Proceedings of the 2015 Symposium on Piezoelectricity, Acoustic Waves, and Device Applications. Jinan, China.

Liu, Y., He, F., Shi, Y., Zhang, B., Duan, C. Q. (2018) Effect of the high pressure treatments on the physicochemical properties of the young red wines supplemented with pyruvic acid. Innovative Food Science \& Emerging Technologies, 48 56-65.

Lopes, P., Saucier, C., Teissedre, P. L., Glories, Y. (2007) Oxygen transmission through different closures into wine bottles. July/August, 2.

Lopes, P., Silva, M. A., Pons, A., Tominaga, T., Lavigne, V., Saucier, C., Darriet, P., Teissedre, P. L., Dubourdieu, D. (2009) Impact of oxygen dissolved at bottling and transmitted through closures on the composition and sensory properties of a Sauvignon blanc wine during bottle storage. Journal of Agricultural and Food Chemistry, 57(21) 10261-10270.

Luo, H., Schmid, F., Grbin, P. R., \& Jiranek, V. (2012) Viability of common wine spoilage organisms after exposure to high power ultrasonics. Ultrasonics sonochemistry, 19(3) 415-420.

Martín, J. F. G. (Ed.). (2016) Applications of Ultrasound in the Beverage Industry. Nova Science Publishers Inc., New York, USA.

Martin, J. F. G., Sun, D. W. (2013) Ultrasound and electric fields as novel techniques for assisting the wine ageing process: The state-of-the-art research. Trends in Food Science \& Technology, 33(1) 40-53.

Mok, C., Song, K. T., Park, Y. S., Lim, S., Ruan, R., Chen, P. (2006) High hydrostatic pressure pasteurization of red wine. Journal of Food Science, 71(8) M265-M269.

Morata, A., Benito, S., González, M. C., Palomero, F., Tesfaye, W., Suárez-Lepe, J. A. (2012) Cold pasteurisation of red wines with high hydrostatic pressure to control Dekkera/Brettanomyces: effect on both aromatic and chromatic quality of wine. European Food Research and Technology, 235(1) $147-154$.

Morozova, K. (2014) Impact of oxygen on quality of white wine (Doctoral dissertation). Retrieved from //opus.uni-hohenheim.de/volltexte/2014/927/pdf/Diss_Influence_of_oxygen_on_white_wine_quality_Ksenia_morozova.pdf

Norton, T., Sun, D. W. (2008) Recent advances in the use of high pressure as an effective processing technique in the food industry. Food and Bioprocess Technology, 1(1) 2-34.

Panero, L., Motta, S., Petrozziello, M., Guaita, M., Bosso, A. (2015) Effect of $\mathrm{SO}_{2}$, reduced glutathione and ellagitannins on the shelf life of bottled white wines. European Food Research and Technology, 240(2) 345-356.

Peynaud, E. (1984) Knowing and making wine. John Wiley, New York, USA.

Plaza, E. G., Jurado, R., Iniesta, J. A., Bautista-Ortín, A. B. (2019) High power ultrasounds: A powerful, non-thermal and green technique for improving the phenolic extraction from grapes to must during red wine vinification. In: BIO Web of Conferences - volume 12, Proceedings of the $41^{\text {st }}$ World Congress of Vine and Wine. Punta del Este, Uruguay.

Puig, A., Olmos, P., Quevedo, J. M., Guamis, B., Mínguez, S. (2008) Microbiological and sensory effects of musts treated by high-pressure homogenization. Food Science and Technology International, 14(5_suppl) 5-11.

Ribéreau-Gayon, P., Glories, Y. A., Maujean, A., Dubourdieu, D. (2000) Handbook of enology, Volume 2: The chemistry of wine stabilization and treatments. Wiley \& Sons, New York, USA. 
Santos, M. C., Nunes, C., Ferreira, A. S., Jourdes, M., Teissedre, P. L., Rodrigues, A., Amado, O., Saraiva, J. A., Coimbra, M. A. (2019) Comparison of high pressure treatment with conventional red wine aging processes: impact on phenolic composition. Food research international, 116 223-231.

Santos, M. C., Nunes, C., Jourdes, M., Teissedre, P. L., Rodrigues, A., Amado, O., Saraiva, J. A., Coimbra, M. A. (2016) Evaluation of the potential of high pressure technology as an enological practice for red wines. Innovative Food Science \& Emerging Technologies, 33 76-83.

Singleton, V. L., Draper, D. E. (1963) Ultrasonic Treatment with Gas Purging as a Quick Aging Treatment for Wine. American Journal of Enology and Viticulture, 14 23-35.

Skouroumounis, G. K., Kwiatkowski, M. J., Francis, I. L., Oakey, H., Capone, D. L., Duncan, B., Sefton, M. A., Waters, E. J. (2005) The impact of closure type and storage conditions on the composition, colour and flavour properties of a Riesling and a wooded Chardonnay wine during five years' storage. Australian Journal of Grape and Wine Research, 11(3) 369-377.

Tabilo-Munizaga, G., Gordon, T. A., Villalobos-Carvajal, R., Moreno-Osorio, L., Salazar, F. N., Pérez-Won, M., Acuña, S. (2014) Effects of high hydrostatic pressure (HHP) on the protein structure and thermal stability of Sauvignon blanc wine. Food chemistry, 155 214-220.

Tao, Y., García, J. F., Sun, D. W. (2014) Advances in wine aging technologies for enhancing wine quality and accelerating wine aging process. Critical reviews in food science and nutrition, 54(6) 817-835.

Tao, Y., Sun, D. W., Górecki, A., Błaszczak, W., Lamparski, G., Amarowicz, R., Fornal, J., Jeliński, T. (2012). Effects of high hydrostatic pressure processing on the physicochemical and sensorial properties of a red wine. Innovative Food Science \& Emerging Technologies, $16409-416$.

Tomašević, M. (2017) Influence of oenological practices on the aroma composition of Pošip wine. PhD thesis submitted at University of Zagreb.

Ugliano, M. (2013) Oxygen contribution to wine aroma evolution during bottle aging. Journal of Agricultural and Food Chemistry, 61(26) 61256136.

van Wyk, S., Farid, M. M., Silva, F. V. (2018) $\mathrm{SO}_{2}$, high pressure processing and pulsed electric field treatments of red wine: Effect on sensory, Brettanomyces inactivation and other quality parameters during one year storage. Innovative Food Science \& Emerging Technologies, $48204-211$.

Vidal, J. C., Moutounet, M. (2006) Monitoring of oxygen in the gas and liquide phases of bottles of wine at bottling and during storage. OENO One, 40(1) 35-45.

Waterhouse, A. L., Frost, S., Ugliano, M., Cantu, A. R., Currie, B. L., Anderson, M., Chassy, A. W., Vidal, S., Diéval J. B., Aagaard, O., Heymann, H. (2016) Sulfur dioxide-oxygen consumption ratio reveals differences in bottled wine oxidation. American Journal of Enology and Viticulture, 67(4) 449-459.

Waterhouse, A. L., Laurie, V. F. (2006) Oxidation of wine phenolics: A critical evaluation and hypotheses. American Journal of Enology and Viticulture, 57 306-313.

Wirth, J., Caillé, S., Souquet, J. M., Samson, A., Dieval, J. B., Vidal, S., Fulcrand, H., Cheynier, V. (2012) Impact of post-bottling oxygen exposure on the sensory characteristics and phenolic composition of Grenache rosé wines. Food chemistry, 132(4) 1861-1871.

Zhang, Q. A., Shen, Y., Fan, X. H., Martín, J. F. G., Wang, X., Song, Y. (2015) Free radical generation induced by ultrasound in red wine and model wine: An EPR spin-trapping study. Ultrasonics sonochemistry, 27 96-101.

Zhang, Q. A., Wang, T. T. (2017) Effect of ultrasound irradiation on the evolution of color properties and major phenolic compounds in wine during storage. Food chemistry, 234 372-380. 